\title{
PENGEMBANGAN PERANGKAT PEMBELAJARAN KOMPETENSI SULIT MATEMATIKA SMA DI RIAU
}

\author{
Ummi Aisyah ${ }^{1)}$, Heri Retnawati ${ }^{2)}$ \\ SMA Negeri 1 Pangkalan Kerinci Pelalawan Riau ${ }^{1)}$ Universitas Negeri Yogyakarta ${ }^{2)}$ \\ aisyah.ummi1@gmail.com ${ }^{1)}$, retnawati_heriuny@yahoo.co.id ${ }^{2)}$
}

\begin{abstract}
Abstrak
Tujuan penelitian ini adalah untuk menghasilkan perangkat pembelajaran kompetensi sulit matematika SMA di Provinsi Riau yang berkualitas baik/layak yaitu valid, praktis, dan efektif. Penelitian ini merupakan penelitian pengembangan yang mengembangkan perangkat pembelajaran kompetensi sulit matematika SMA dengan menggunakan model pengembangan 4-D yang dikembangkan oleh Thiagarajan, Semmel \& Semmel yang telah dimodifikasi sehingga hanya memuat tahap pendefinisian, perancangan, dan pengembangan. Penelitian ini menghasilkan perangkat pembelajaran kompetensi sulit matematika SMA yang meliputi silabus, rencana pelaksanaan pembelajaran (RPP), lembar kegiatan siswa (LKS), dan instrumen tes. Hasil validasi menunjukkan bahwa silabus, RPP, LKS yang dikembangkan memiliki kategori sangat valid untuk masing-masing silabus, RPP, LKS, dan test instrument. Hasil uji coba lapangan menunjukkan bahwa perangkat yang dikembangkan praktis dan efektif. Kepraktisan mencapai hasil sangat baik ditinjau dari penilaian guru dan siswa. Keefektifan ditinjau dari ketuntasan belajar siswa dan hasil observasi keterlaksanaan pembelajaran. Secara klasikal ketuntasan belajar mencapai $84,38 \%$. Secara keseluruhan, hasil penelitian menunjukkan bahwa perangkat pembelajaran yang dikembangkan adalah layak untuk digunakan.
\end{abstract}

Kata Kunci: pengembangan, perangkat pembelajaran, kompetensi sulit matematika

\section{DEVELOPING DIFFICULT COMPETENCE MATHEMATICS TEACHING PACKAGE FOR SENIOR HIGH SCHOOLS IN RIAU PROVINCE}

\begin{abstract}
This study aims to produce difficult competence mathematics teaching package for senior high schools, which is in good quality/feasible, valid, practical and effective. This study was a research and development which developed difficult compentence mathematics teaching package for senior high schools, using the 4-D development model that was developed by Thiagarajan, Semmel and Semmel and the model was modified so that it included only define, design and develop stages. This study produces difficult competence mathematics teaching package for senior high schools including a syllabus, lesson plans, worksheets, and test instrument. The results of the validation show that the developed package is in a very valid category based on syllabus, lesson plans, worksheets, and learning achievement test. The results of the tryout indicate that the developed package is practical and effective. The practicality is in the good category based on student assessment, teacher assessment, and observation of learning implementation sheet. The effectiveness is based on the students' learning mastery. Classically, the learning mastery is 84.38. Overall, the results of this study show that the developed learning package is feasible to use.
\end{abstract}

Keywords: development, learning pack, difficult competences mathematics. 


\section{PENDAHULUAN}

Pendidikan merupakan kebutuhan bagi setiap manusia. Pendidikan adalah kunci dalam menjalani kehidupan. Sebagaimana yang dinyatakan dalam organisasi dunia yaitu UNESCO, jika ingin membangun dan berusaha memperbaiki keadaan suatu bangsa, maka haruslah dari pendidikan, sebab pendidikan adalah kunci menuju perbaikan terhadap peradaban. Adapun salah satu pendidikan yang penting dikuasai oleh manusia yaitu pendidikan matematika. Dalam Depdiknas (2006, p.388) disebutkan lima tujuan siswa belajar matematika diantaranya yaitu memahami konsep matematika, menjelaskan keterkaitan antarkonsep dan mengaplikasikan konsep atau algoritma, secara luwes, akurat, efisien, dan tepat, dalam pemecahan masalah. Dari tujuan siswa belajar matematika tersebut menunjukkan bahwa matematika sangat penting dalam kehidupan manusia karena dapat menjadi landasan untuk berpikir, bernalar, percaya diri dalam memecahkan masalah dan menarik ke- simpulan, sehingga dengan belajar matematika manusia akan terbantu dalam memahami, dan memecahkan berbagai permasalahan dalam kehidupannya belum memperoleh hasil yang menggembirakan.

Berdasarkan hasil analisis UN ada beberapa kompetensi yang diujikan memperoleh daya serap di bawah $65 \%$. Diantaranya yaitu kompetensi menyelesaikan persamaan trigonometri pada SK "menggunakan perbandingan, fungsi, persamaan, dan identitas trigonometri dalam pemecahan masalah" sebanyak tiga kali berturutturut yaitu pada tahun 2012, 2011 dan 2010 memperoleh daya serap $<65 \%$, sehingga kompetensi tersebut termasuk kategori kompetensi sulit. Hal ini terjadi di SMAN 1 Pangkalan Kerinci dan di SMAN 1 Tualang. Kompetensi sulit pada UN dinyatakan berdasarkan proporsi siswa menjawab benar yang kurang dari $65 \%$. Untuk lebih jelasnya dapat dilihat Tabel Daya Serap UN siswa untuk kompetensi menyelesaikan persamaan trigonometri.

Tabel 1. Proporsi Menjawab Benar butir Soal Matematika UN 2010-2012

\begin{tabular}{llcccc}
\hline \multirow{2}{*}{ Tahun } & \multicolumn{1}{c}{ Kompetensi } & \multicolumn{4}{c}{ Daya Serap Siswa (\%) } \\
\cline { 3 - 6 } & & $\begin{array}{c}\text { SMAN 1 } \\
\text { Tualang }\end{array}$ & $\begin{array}{c}\text { SMAN 1 } \\
\text { Pangkalan } \\
\text { Kerinci }\end{array}$ & $\begin{array}{c}\text { Provinsi } \\
\text { Riau }\end{array}$ & Nasional \\
\hline 2012 & Menyelesaikan persamaan trigonometri & 78,1 & 59,9 & 68,4 & 68,42 \\
2011 & Hitung nilai perbandingan trigonometri dengan & 60,1 & 73,8 & 72,1 & 72,05 \\
& rumus jumlah, selisih dua sudut, jumlah, selisih & & & & \\
& sin, cos, tan. & & & & \\
2010 & Menyelesaikan persamaan trigonometri & 77,0 & 32,4 & 87,3 & 87,30 \\
\hline
\end{tabular}

Selanjutnya dari hasil wawancara dengan guru matematika SMAN 1 Tualang dan SMAN 1 Pangkalan Kerinci, kompetensi "menyelesaikan persamaan trigonometri" termasuk kategori kompetensi sulit di SMAN 1 Pangkalan Kerinci dan di SMAN 1 Tualang. Demikian halnya hasil wawancara dengan siswa-siswa kelas XI \& XII SMAN 1 Tualang dan siswa SMAN 1 Pangkalan Kerinci.

Berdasarkan analisis daya serap hasil UN siswa dari tahun 2010-2012 dan hasil peneliti dengan siswa-siswa kelas XI \& XII SMAN 1 Tualang, serta dari para guru matematika SMAN 1 Tualang dapat disimpulkan bahwa kompetensi "menyelesaikan persamaan trigonometri" pada materi trigonometri dengan Standar Kompetensi "menggunakan perbandingan, fungsi, persamaan, dan identitas trigonometri dalam pemecahan masalah" termasuk kategori kompetensi sulit di
SMAN 1 Tualang yang perlu segera diberikan solusi agar keluar dari permasalahannya.

Munculnya Kompetensi Dasar (KD) sulit matematika tersebut tentu dipengaruhi oleh beberapa faktor diantaranya faktor dari guru, dan faktor dari dalam diri siswa. Berdasarkan informasi dari beberapa guru yang menyebabkan trigonometri sulit dipelajari oleh siswa karena banyaknya rumus yang harus dipelajari dan dihafalkan, misalnya rumus-rumus perbandingan trigonometri pada segitiga siku-siku, rumusrumus sudut berelasi, perbandingan trigonometri sudut khusus, rumus aturan sinus dan cosinus, identitas-identitas trigonometri, rumus luas segitiga dan lain-lain. Demikian halnya hasil wawancara dengan siswa, trigonometri sulit dipelajari karena banyak rumus yang harus dihafalkan dan tidak mungkin mengingat semua rumus ketika melaksanakan ujian dan kemanfaatannya juga tidak ada dalam kehidupan sehari-hari. 
Memperhatikan permasalahan yang dihadapi guru dan siswa tersebut diperlukan pengembangan suatu perangkat pembelajaran dengan model pembelajaran tertentu yang menuntut siswa aktif mengembangkan sendiri pengetahuannya, bukan hanya menerima dan menghafal informasi dari guru. Selain daripada itu yang tidak kalah pentingnya materi yang dipelajari praktis, dapat diketahui dan dirasakan manfaatnya oleh siswa dalam kehidupan seharihari. Dalam Depdiknas (2007, p.3) disebutkan bahwa pemilihan metode pembelajaran seharusnya disesuaikan dengan situasi dan kondisi peserta didik, serta karakteristik dari setiap indikator kompetensi yang hendak dicapai pada setiap mata pelajaran, agar tercapai kompetensi dasar atau seperangkat indikator yang telah ditetapkan. Demikian juga yang dinyatakan dalam (Depdiknas, 2006, p.387) yaitu dalam setiap kesempatan, pembelajaran matematika hendaknya dimulai dengan pengenalan masalah yang sesuai dengan situasi (contextual problem). Dengan mengajukan masalah kontekstual, peserta didik secara bertahap dibimbing untuk menguasai konsep matematika.

Salah satu model pembelajaran yang menuntut siswa untuk mengembangkan sendiri pengetahuannya dan untuk mengintegrasikan pengetahuan baru selalu dimulai dengan permasalahan kehidupan nyata sehari-hari adalah model pembelajaran problem based learning (PBL). Model pembelajaran PBL adalah model pembelajaran yang menyajikan masalah kehidupan nyata sehari-hari sebagai titik awal pembelajaran untuk memperoleh atau mengintegrasikan pengetahuan baru. Belajar akan lebih bermakna ketika siswa mengeksplorasi lingkungan-lingkungan belajar mereka daripada secara pasif mendengarkan guru menerangkan (Schunk, 2008, p.267).

Barrows \& Tamblyn (Cheong, 2008, p.49) mendefinisikan PBL yaitu pembelajaran yang dihasilkan dari proses bekerja menuju pemahaman dan resolusi dari masalah dalam konteks kehidupan nyata sehari-hari. Lebih lanjut Cheong menyatakan bahwa pembelajaran PBL berbeda dengan pembelajaran konvensional yaitu siswa memperoleh dan menyerap informasi dari guru-guru mereka dan menggunakannya untuk memecahkan masalah dalam rangka untuk menentukan tingkat pemahaman dan penerapan dari materi pelajaran. Dalam pembelajaran dengan model PBL, siswa disajikan dengan situasi yang mengarahkan siswa untuk memecahkannya. Siswa belajar melalui tindakan mencoba untuk memecahkan masalah. Mereka menganalisis masalah, mengumpulkan informasi, menghasilkan dan mengevaluasi solusi yang mungkin untuk menemukan satu solusi yang terbaik dan kemudian menyajikan kesimpulan mereka. Sering, jawaban dari masalah tidak hanya satu jawaban yang benar.

Arends \& Kilcher (2010, p.326) mendefinisikan pembelajaran berbasis masalah adalah pembelajaran yang berpusat pada siswa yang mengatur kurikulum dan pengajaran yang dibuat di sekitar kita (ill-structured) dan masalah yang disajikan ada dalam dunia nyata. Dalam pembelajaran PBL yaitu "students make a greater attempt to understand and remember when they see connections between the material they study and their own lives" (Delisle, 1997, p.8). Maksud dari pernyataan Delisle tersebut adalah pada pembelajaran PBL siswa membuat upaya yang lebih besar untuk memahami ketika mereka ingat dan melihat hubungan antara materi yang mereka pelajari dengan kehidupan mereka sendiri.

Selanjutnya Arends (2007, p.396) mengungkapkan tentang PBL "the essence problem based learning consists of presenting student with authentic and meaningful problem situations that can serves as springboards for investigations and inquiry". Maksudnya yaitu masalah esensi dalam pembelajaran berbasis masalah adalah guru menyajikan kepada siswa masalah otentik dan bermakna yang akan berfungsi sebagai batu loncatan untuk investigasi dan penyelidikan. PBL dimulai dengan suatu masalah, kasus, atau masalah tidak-terstruktur yang dapat diteliti, dipelajari, atau bahkan "dipecahkan.

"Solusi," akan tetapi, tidak memiliki satu jawaban yang benar. Sebaliknya, banyak jalan solusi dan beberapa jawaban yang baik dapat dibuat. Berbeda teknik pemecahan masalah dapat diterapkan ke masalah awal, dan kelompokkelompok atau individu pada umumnya mencapai suatu solusi yang mungkin atau masuk akal (Levin, 2001, p.2). Selanjutnya Smith (Amir, 2009, p.27) menyatakan pembelajaran dengan menggunakan model PBL akan dapat meningkatkan kecakapan pemecahan masalah siswa, meningkatkan pengetahuannya yang relevan dengan dunia praktik, mendorong mereka penuh pemikiran, membangun kemampuan kepemimpinan dan bekerja sama, kecakapan belajar, dan memotivasi pembelajaran. PBL adalah suatu model pembelajaran yang memberikan kesempatan bagi peserta didik untuk mengkonstruksi sendiri pengetahuannya. Penerapan model PBL 
sangat bermanfaat bagi peserta didik dan guru. Peserta didik dapat mengembangkan sendiri kemampuannya melalui perangkat-perangkat yang dipersiapkan oleh guru. Dalam PBL, guru memberikan beberapa masalah dan pertanyaan, memfasilitasi atau membimbing penyelidikan, dan memfasilitasi dialog antarsiswa yang bekerja dalam kelompok-kelompok kerja yang sistematis sehingga ide-ide berbeda dan beragam yang telah dimiliki oleh peserta didik akan muncul kembali yang kemudian akan terbentuk ideide atau pengetahuan baru. Dengan demikian, perlu dikembangkan suatu model pembelajaran matematika berbasis masalah yang termuat dalam perangkat pembelajaran. Adapun perangkat tersebut terdiri atas beberapa unsur yaitu silabus, rencana pelaksanaan pembelajaran (RPP), lembar kegiatan siswa (LKS), dan instrumen tes. Model pembelajaran PBL yang dikembangkan ini perlu diuji kevalidan, kepraktisan, dan keefektifannya sebelum digunakan di lingkungan sekolah, sehingga diperlukan suatu penelitian yang menghasilkan produk berupa model pembelajaran PBL tersebut. Penelitian yang sesuai adalah penelitian dan pengembangan (Research and Development).

\section{METODE PENELITIAN}

\section{Model Pengembangan}

Penelitian ini merupakan penelitian pengembangan. Penelitian difokuskan pada pengembangan produk yang berupa perangkat pembelajaran matematika dengan menggunakan model pembelajaran PBL untuk pembelajaran kompetensi sulit matematika SMA di Riau. Model pengembangan yang digunakan dalam penelitian ini adalah model 4-D yang dikembangkan oleh Thiagarajan, Semmel \& Semmel. Adapun perangkat yang dikembangkan adalah silabus, RPP, LKS, dan instrumen tes. Materi yang digunakan dalam pengembangan ini adalah materi trigonometri dengan SK "menggunakan perbandingan, fungsi, persamaan, dan identitas trigonometri dalam pemecahan masalah". Dalam pengembangan perangkat secara prinsip dinyatakan oleh Thiagrajan, Semmel \& Semmel terdiri dari 4 tahap yaitu tahap pendefinisian, perancangan, pengembangan, dan penyebaran. Pada penelitian ini tidak dilakukan tahap penyebaran, yang dilakukan hanya 3 tahap dan dimodifikasi pada bagian-bagian tertentu. Modifikasi yang dimaksud yaitu: (1) analisis konsep dimodifikasi menjadi analisis materi, karena dalam pembelajaran matematika yang dipelajari tidak hanya konsep tetapi juga fakta, prinsip, dan keterampilan, (2) spesifikasi tujuan pembelajaran dimodifikasi menjadi perumusan indikator, karena dalam KTSP tidak terdapat tujuan pembelajaran umum dan tujuan pembelajaran khusus, (3) sebelum pemilihan media, peneliti menyusun perencanaan prosedur kerja sebagai prediksi waktu yang dibutuhkan selama penelitian, (4) penyusunan tes dilakukan pada saat perancangan awal, (6) pada tahap pengembangan perangkat dilakukan uji coba terbatas untuk mengetahui apakah ada kata atau kalimat yang kurang jelas dari perangkat yang dikembangkan. Selanjutnya, peneliti menggunakan langkah-langkah pengembangan dengan melakukan modifikasi sesuai dengan beberapa pernyataan tersebut. Langkahlangkah pada tahap pendefinisian dan perancangan yang dilakukan ditunjukkan pada Gambar 1 berikut.

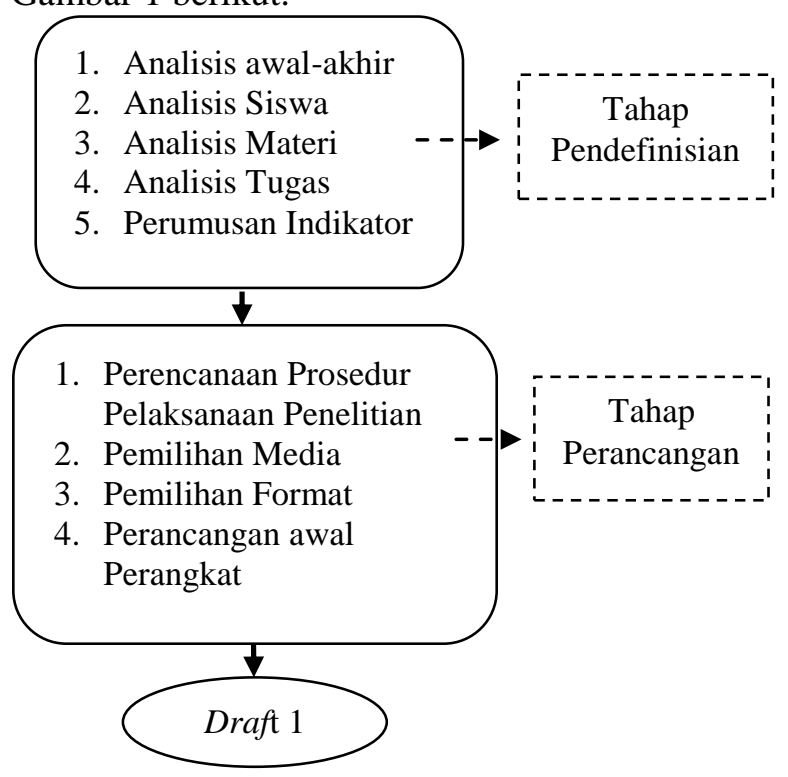

Gambar 1. Tahap Pendefinisian dan Perencanaan

Setelah menghasilkan suatu perangkat dari tahap pendefinisian dan perancangan pada draft 1, maka dilakukan tahap pengembangan. Tahap pengembangan dilakukan untuk melihat kualitas perangkat, yakni kevalidan, kepraktisan, dan keefektifan perangkat. Berikut langkahlangkah pengembangan yang akan dilakukan. 


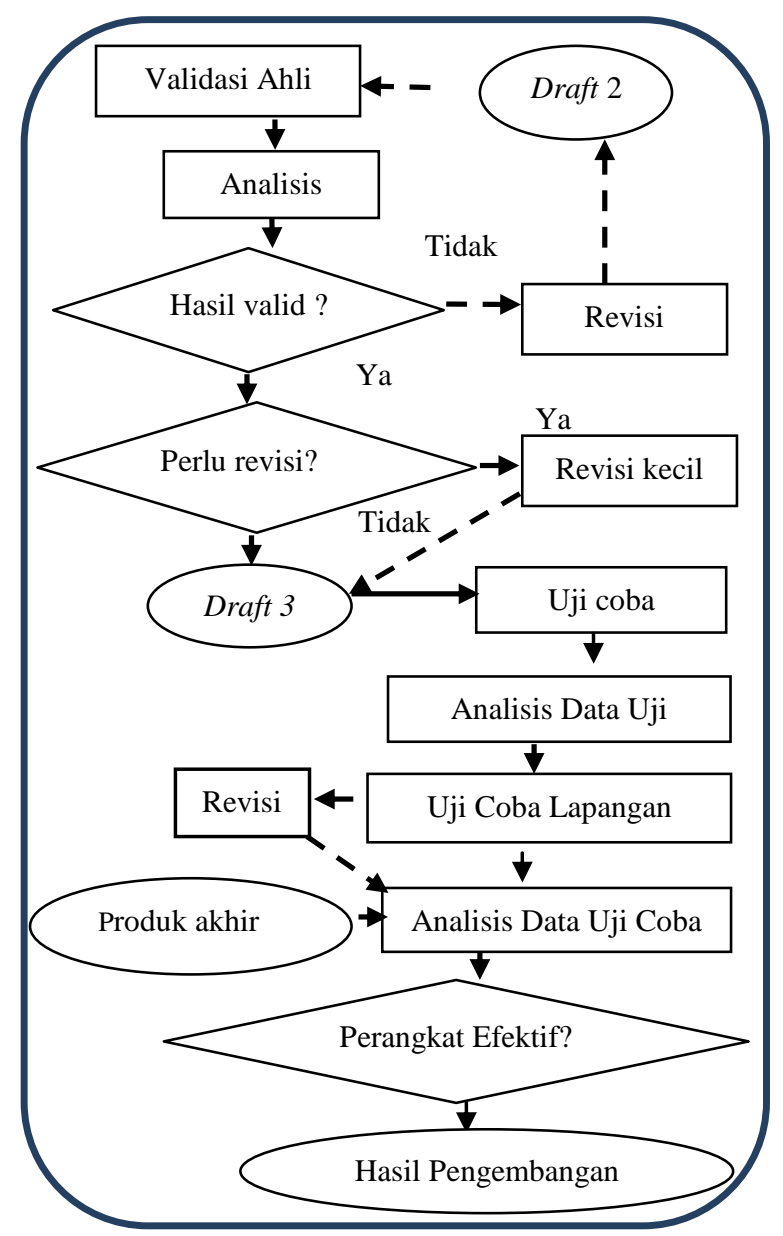

Gambar 2. Tahap Pengembangan

\section{Prosedur Pengembangan}

Langkah-langkah yang akan dilaksanakan dalam prosedur pengembangan antara lain: (1) tahap pendefinisian yaitu: analisis awal-akhir, analisis siswa, analisis materi, analisis tugas, dan perumusan indikator, (2) tahap perancangan yaitu: pemilihan media, pemilihan format, perancangan awal (silabus, RPP, LKS, dan instrumen tes) dan hasil rancangan awal ini dinamakan draft 1, (3) tahap pengembangan yaitu: Validasi Ahli dilakukan untuk memperoleh penilaian atau menguji validitas desain awal perangkat (draft 1) oleh para ahli bidang matematika SMA/MA, kemudian data validasi yang diperoleh dari ahli dianalisis, jika desain awal (draft 1) belum valid maka dilakukan revisi $1 a$ sehingga memperoleh (draft 2a). Jika desain awal (draft 1) sudah valid, tetapi masih perlu direvisi maka dilakukan revisi $1 b$, perangkat pembelajaran yang direvisi merupakan bentuk (draft 2b). Hasil draft 2b inilah yang kemudian akan diujicobakan pada uji coba terbatas.

\section{Uji Coba Terbatas}

Draft $2 b$ kemudian diujicobakan yang dinamakan uji coba terbatas. Uji coba dilakukan 2 kali pada 3 orang guru mitra dan 8 orang siswa SMAN 1 Tualang. Guru mitra menilai keterbacaan silabus, RPP, LKS, dan instrumen tes. Sedangkan siswa menilai keterbacaan dan mempelajari LKS dan instrumen tes. Kemudian data uji coba terbatas dianalisis untuk mengetahui apakah perangkat yang dikembangkan telah memenuhi kriteria kepraktisan. Dari hasil uji coba terbatas kemudian dilakukan revisi 2 terhadap perangkat yang dikembangkan. Dari hasil revisi 2 akan dihasilkan draft 3 . Draft 3 yang digunakan pada uji coba lapangan.

\section{Uji Coba Lapangan}

Draft 3 kemudian diujicobakan pada subjek yang lebih luas. Uji coba lapangan dilakukan pada siswa kelas X2 dan X3 SMAN 1 Tualang. Dalam uji coba lapangan ini, pembelajaran dilaksanakan selama 8 kali pertemuan. Kemudian data uji coba lapangan berdasarkan masukan dari guru mitra dilakukan revisi 3 pada produk yang dikembangkan. Setelah semua hasil analisis menunjukkan kategori valid, praktis, dan efektif, maka dihasilkan produk yang baik.

\section{Desain Uji Coba Produk}

\section{Desain Uji Coba}

Desain uji coba pada penelitian ini terdiri dari 3 tahap yaitu: (1) uji coba ahli/validasi ahli yang mana hasil validasi akan dijadikan bahan untuk merevisi produk awal. Validasi juga dilakukan dengan meminta penilaian dari 3 guru matematika SMA yang mengajar materi trigonometri. Apabila sudah valid maka perangkat diujicobakan pada uji coba terbatas, (2) uji coba terbatas, dilakukan untuk menguji apakah kualitas perangkat pembelajaran yang dihasilkan telah terpenuhi dari segi kepraktisannya. Tindakan yang dilakukan adalah dengan meminta penilaian dari 8 orang siswa SMAN 1 Tualang yang dipilih berdasarkan kemampuan akademik yaitu tinggi, sedang, dan kurang. Siswa tersebut diminta untuk membaca dan mempelajari perangkat pembelajaran yang dihasilkan, kemudian diminta memberikan komentar/masukan tentang perangkat pembelajaran tersebut. Berdasarkan masukan tersebut dilakukan revisi 2 terhadap perangkat, maka diperoleh perangkat pembelajaran yang siap digunakan pada uji coba lapangan, (3) uji coba lapangan yaitu dilakukan untuk mengetahui kualitas perangkat pembel- 
ajaran yang dihasilkan dilihat dari segi kepraktisan dan keefektifannya. Uji coba lapangan akan dilakukan pada kelas X2 dan X3 yang diajar oleh guru mitra. Pada tahap ini akan dilaksanakan pembelajaran dengan menggunakan perangkat pembelajaran yang dihasilkan. Kemudian siswa mengikuti tes untuk melihat keefektifan perangkat pembelajaran tersebut.

\section{Subjek Uji Coba dan Waktu Penelitian}

Subjek uji coba lapangan adalah siswa kelas X2 dan X3 SMAN 1 Tualang tahun ajaran 2013 yang masing-masing kelas berjumlah 32 orang. Uji coba lapangan dilaksanakan pada bulan Maret-April 2013.

\section{Jenis Data}

Data yang akan diperoleh dari penelitian ini berupa data validasi ahli mengenai kelayakan instrumen, data validasi ahli dan praktisi mengenai validitas perangkat yang dikembangkan (silabus, RPP, LKS, dan instrumen tes), data hasil uji coba terbatas (data penilaian guru dan siswa), data uji coba lapangan (data hasil observasi keterlaksanaan pembelajaran, dan data hasil belajar siswa).

\section{Instrumen Pengumpulan Data}

Instrumen yang akan diguanakan dalam penelitian ini adalah 5 item yaitu: (1) instrumen mengukur kevalidan perangkat pembelajaran yaitu lembar validasi silabus yaitu produk awal silabus dikembangkan berdasarkan langkahlangkah penyusunan silabus serta prinsip-prinsip yang perlu diperhatikan dalam penyusunan silabus. Silabus disusun untuk pembelajaran satu standar kompetensi (SK) yang memuat materi trigonometri, (2) lembar validasi RPP yaitu digunakan untuk mengukur kevalidan RPP yang telah disusun berdasarkan komponen-komponen penyususnan RPP serta prinsip-prinsip yang perlu diperhatikan dalam penyusunan RPP. Langkah-langkah dalam kegiatan pembelajaran dirancang sesuai dengan model pembelajaran yang digunakan yaitu PBL. RPP yang akan dirancang adalah satu SK yang terdiri dari tiga kompetensi dasar (KD), dan tiga KD tersebut akan dirancang dalam delapan kali pertemuan, (3) lembar validasi LKS yaitu dikembangkan sesuai syaratsyarat dalam penyusunan lembar kegiatan siswa (LKS). LKS dirancang untuk setiap pertemuan sesuai dengan skenario pembelajaran yang termuat dalam RPP yaitu sebanyak 8 lembar kegiatan siswa (LKS). Lembar kegiatan siswa (LKS) dirancang sedemikian hingga yaitu tam- pilan (tulisan, ilustrasi, gambar) jelas dan menarik, masalah yang disajikan relevan dalam kehidupan nyata sehari-hari, mudah digunakan, informasi dan petunjuk mengerjakan jelas, bahasa dan daya pikir yang sesuai dengan siswa, waktu yang cukup untuk memanfaatkan pengetahuan dan keterampilan siswa, dan tersedianya tempat yang cukup bagi siswa untuk menuliskan ide-ide mereka dalam proses menemukan konsep-konsep atau pengetahuan baru.

\section{Instrumen Mengukur Kepraktisan Perangkat}

Instrumen untuk mengukur kepraktisan perangkat pembelajaran adalah: (1) lembar penilaian praktisi yaitu digunakan untuk memperoleh data tentang kepraktisan perangkat yang dikembangkan. Penilaian dilakukan oleh guru sebagai praktisi di lapangan setelah melakukan pembelajaran. Hal ini dilakukan untuk mengetahui apakah perangkat pembelajaran yang dihasilkan telah layak dan dapat digunakan dalam pembelajaran di kelas. Perangkat tersebut terdiri dari silaus, RPP, dan LKS. Penentuan skor dibuat dalam skala 5 penilaian, yaitu: tidak praktis nilai 1 , kurang praktis nilai 2, cukup praktis nilai 3, praktis nilai 4, sangat praktis nilai 5, (2) lembar penilaian siswa digunakan untuk memperoleh data mengenai pendapat siswa tentang penggunaan LKS. Penilaian dilakukan oleh siswa setelah melakukan pembelajaran dengan menggunakan model pembelajaran PBL. Hal ini dilakukan untuk mengetahui apakah perangkat yang dihasilkan layak untuk diterapkan di kelas. Penentuan skor dibuat dalam skala 5 penilaian, yaitu: tidak praktis (nilai 1), kurang praktis (nilai 2), cukup praktis (nilai 3), praktis (nilai 4), dan sangat praktis (nilai 5).

\section{Instrumen Mengukur Keefektifan}

Instrumen mengukur keefektifan yaitu: (1) lembar observasi keterlaksanan pembelajaran digunakan untuk mengetahui tingkat keterlaksanaan perangkat pembelajaran yang dikembangkan. Indikator untuk menyatakan keterlaksanaan perangkat pembelajaran di sekolah dikatakan "baik" dengan melihat apakah komponenkomponen perangkat pembelajaran dapat dilaksanakan oleh guru dalam pembelajaran di kelas. Instrumen ini dibuat berdasarkan tahapan-tahapan yang dijabarkan dalam RPP dan diisi oleh pengamat. (2) THB digunakan untuk memperoleh data hasil belajar siswa dengan menggunakan model pembelajaran PBL. Tingkat ketercapaian siswa diukur dari ketercapaian kompetensi dasar pada materi trigonometri sesuai 
indikator yang ditetapkan. Penyusunan tes hasil belajar diawali dengan penyusunan kisi-kisi soal berbentuk pilihan ganda (multiple-choice item) yang terdiri dari 15 soal dan tes uraian (essay test) 5 soal.

\section{Teknik Analisis Data}

Data yang diperoleh dari angket validasi ahli dianalisis berdasarkan langkah-langkah berikut: (1) penilaian oleh ahli dirangkum dalam satu tabel yang disebut tabel hasil penilaian kelayakan perangkat pembelajaran, (2) pemeriksaan terhadap setiap hasil penilaian oleh ahli, (3) kriteria yang digunakan yaitu kriteria jika frekuensi data layak digunakan (LD) atau layak digunakan dengan revisi (LDR) lebih banyak dibandingkan dengan frekuensi data tidak layak digunakan (TLD), maka perangkat tersebut dilanjutkan penggunaannya. Jika ada masukan yang diberikan ahli dan dituliskan pada instrumen yang dinilai, maka akan dijadikan pertimbangan untuk melakukan revisis. Revisi dilakukan bertujuan untuk menghasilkan produk pengembangan perangkat yang baik dan dapat digunakan sebagai uji coba terbatas dan uji coba lapangan.

\section{Analisis Data Kelayakan Instrumen}

Analisis data dilakukan untuk mendapatkan bukti penilaian kelayakan instrumen yang akan digunakan dalam mengukur kevalidan kepraktisan, dan keefektifan perangkat yang dihasilkan. Analisis yang digunakan adalah kesesuaian instrumen dengan teori yang akan diukur dalam menentukan kevalidan, kepraktisan dan keefektifan perangkat yang akan dinilai. Nieveen (1999, pp.127-128) menyatakan kualitas produk pendesainan, pengembangan, dan pengevaluasian program harus memenuhi kriteria valid, praktis, dan efektif. Instrumen yang sudah layak digunakan, dapat digunakan oleh validator. Selanjutnya validator mengukur tingkat kevalidan perangkat berdasarkan instrumen tersebut, untuk instrumen kepraktisan dan keefektifan digunakan peneliti ketika melaksanakan uji coba lapangan.

\section{Analisis Data}

Data yang diperoleh dari para ahli dan praktisi dianalisis untuk menentukan kevalidan perangkat pembelajaran ditinjau secara teoritis dan konsistensi diantara komponen-komponen perangkat pembelajaran. Sedangkan data hasil uji coba di lapangan digunakan untuk menjawab kriteria kepraktisan dan keefektifan perangkat pembelajaran yang dikembangkan. Langkahlangkah yang digunakan untuk memberikan kriteria kualitas terhadap produk yang dikembangkan sebagai berikut: (1) data yang berupa skor tanggapan ahli, praktisi, dan siswa yang diperoleh dalam bentuk kategori yang terdiri dari lima pilihan tanggapan tentang kualitas produk perangkat yang dikembangkan, yaitu sangat baik (nilai 5), baik (nilai 4), cukup baik (nilai 3), kurang baik (nilai 2), dan tidak baik (nilai 1) diubah menjadi data interval, (2) data skor yang diperoleh kemudian dikonversi menjadi data kualitatif skala lima, dengan acuan rumus yang dikutip dari acuan rumus yang diadaptasi dari Azwar (2010, p.163) yang ditunjukkan pada Tabel 2 berikut. $\bar{x}_{i}=$ Rerata skor ideal $=$ $\frac{1}{2}$ (skor maksimum ideal + skor minimum ideal). $S B_{i}=$ Simpangan baku ideal $=\frac{1}{5}$ (skor maksimum ideal-skor minimum ideal). $X=$ Total skor aktual.

Tabel 2. Konversi Skor Aktual menjadi Nilai Skala Lima

\begin{tabular}{ccc}
\hline Nilai & Interval Skor & Kriteria \\
\hline A & $X>\overline{x_{i}}+1,5 S B_{i}$ & Sangat \\
& baik \\
B & $\bar{x}_{i}+S B_{i}<X \leq \bar{x}_{i}+1,5 S B_{i}$ & Baik \\
C & $\bar{x}_{i}-0,5 S B_{i}<X \leq \bar{x}_{i}+1,5 S B_{i}$ & $\begin{array}{c}\text { Sangat } \\
\text { baik }\end{array}$ \\
D & $\bar{x}_{i}-1,5 S B_{i}<X \leq \bar{x}_{i}-0,5 S B_{i}$ & $\begin{array}{c}\text { Kurang } \\
\text { baik }\end{array}$ \\
& $X \leq \bar{x}_{i}-1,5 S B_{i}$ & Tidak \\
E & baik \\
\hline
\end{tabular}

\section{Analisis Data Validitas Perangkat}

Data berupa skor tanggapan validator yang diperoleh dalam bentuk kategori yang terdiri dari lima pilihan tanggapan tentang kualitas perangkat pembelajaran yang dikembangkan yaitu: sangat valid (nilai 5), valid (nilai 4), cukup valid (nilai 3), kurang valid (nilai 2), dan tidak valid (nilai 1). Data skor yang diperoleh dari keenam validator kemudian dikonversikan menjadi data kualitatif skala lima dengan mengadaptasi interval nilai pada Tabel 2, yang diperoleh dengan memasukkan nilai-nilai skor maksimal dan minimal untuk menentukan $\overline{x_{i}}$ dan $S B_{i}$, sehingga diperoleh kriteria interval untuk masing-masing kategori. Banyak item untuk validasi silabus adalah 36 item (skor minimal ideal $=36$, dan skor maksimum ideal $=$ $180, \overline{x_{i}}=108$ dan $S B_{i}=24$ ), banyak item 
validasi untuk RPP adalah 54 item (skor minimal ideal $=270$, dan skor maksimum ideal $=270, \overline{x_{i}}=162$ dan $S B_{i}=36$ ), dan banyak item validasi untuk LKS adalah 23 item (skor minimal ideal $=23$, skor maksimum ideal $=115$, $\overline{x_{i}}=69$ dan $\left.S B_{i}=15,3\right)$, sehingga diperoleh kriteria interval untuk menentukan kategori validitas masing-masing untuk Silabus, RPP, dan LKS, seperti Tabel 3 berikut.

Tabel 3. Kriteria Interval Validitas Perangkat Pembelajaran

\begin{tabular}{ccccc}
\hline & Interval & & Nilai & Kategori \\
\hline Silabus & RPP & LKS & & \\
$X>144$ & $X>216$ & $X>92$ & A & Sangat Valid \\
$132<X \leq 144$ & $198<X \leq 216$ & $84,3<X \leq 92$ & B & Valid \\
$96<X \leq 132$ & $144<X \leq 198$ & $61,3<X \leq 84,3$ & C & Cukup Valid \\
$72<X \leq 96$ & $108<X \leq 144$ & $46<X \leq 61,3$ & D & Kurang Valid \\
$X \leq 72$ & $X \leq 108$ & $X \leq 46$ & E & Tidak Valid \\
\hline
\end{tabular}

\section{Analisis Data Kepraktisan Perangkat}

Data kepraktisan perangkat pembelajaran terdiri dari data hasil penilaian tentang kelayakan penggunaan perangkat pembelajaran berdasarkan penilaian guru dan siswa. Dalam hal ini, guru dan siswa menggunakan produk pada saat uji coba. Skor penilaian yang diperoleh dari guru dan siswa dikonversi menjadi data kualitatif skala 5 dengan mengacu pada konversi Tabel 2. Kemudian data yang diperoleh dari penilaian guru dianalisis. Banyak item untuk penilaian guru adalah 40 item dan penilaian dilakukan oleh satu orang guru (skor maksimal ideal $=200$, skor minimal ideal $=40, \overline{x_{i}}=120$ dan $S B_{i}=$ 26,7), sehingga diperoleh kriteria interval kepraktisan menurut penilaian guru seperti Tabel 4 berikut.
Tabel 4. Kriteria Interval Praktis Menurut Penilaian Guru

\begin{tabular}{ccc}
\hline Interval & Nilai & Kategori \\
\hline $\mathrm{X}>160$ & $\mathrm{~A}$ & Sangat praktis \\
$146,7<\mathrm{X} \leq 160$ & $\mathrm{~B}$ & Praktis \\
$106<\mathrm{X} \leq 146,7$ & $\mathrm{C}$ & Cukup praktis \\
$80<\mathrm{X} \leq 106$ & $\mathrm{D}$ & Kurang praktis \\
$\mathrm{X} \leq 80$ & $\mathrm{E}$ & tidak praktis \\
\hline
\end{tabular}

Berdasarkan aspek-aspek yang digunakan dalam penilaian kepraktisan perangkat pembelajaran menurut guru pada Tabel 4 dan dengan memperhatikan banyaknya item setiap aspek penilaian, maka diperoleh nilai $\overline{x_{i}}$ dan $S B_{i}$ untuk masing-masing aspek penilaian yang dapat dilihat pada Tabel 5 berikut.

Tabel 5. Nilai-Nilai $\bar{x}_{i}$ dan $S B_{i}$ untuk masing-masing Aspek Penilaian Kepraktisan Menurut Guru

\begin{tabular}{cccccc}
\hline Aspek Penilaian & $\begin{array}{c}\text { Banyak } \\
\text { Item }\end{array}$ & $\begin{array}{c}\text { Skor Minimum } \\
\text { Ideal }\end{array}$ & $\begin{array}{c}\text { Skor Maksimum } \\
\text { Ideal }\end{array}$ & $\overline{\boldsymbol{x}_{\boldsymbol{i}}}$ & $\boldsymbol{S B}_{\boldsymbol{i}}$ \\
\hline Silabus & 7 & 7 & 35 & 21 & 4,7 \\
RPP & 10 & 10 & 50 & 30 & 6,7 \\
LKS & 10 & 10 & 50 & 30 & 6,7 \\
Kondisi siswa pada proses pembelajaran & 8 & 8 & 40 & 24 & 5,3 \\
Keterlaksanaan pelaksanaan pembelajaran & 5 & 5 & 25 & 15 & 3,3 \\
\hline
\end{tabular}

Perangkat pembelajaran yang dikembangkan dikatakan praktis jika penilaian perangkat pembelajaran oleh guru minimal berada pada kategori praktis.

\section{Analisis Data Penilaian Siswa}

Analisis data hasil penilaian siswa dilakukan dengan menghitung skor penilaian untuk masing-masing siswa, kemudian mengkonversi kedalam data kualitatif. Banyak item untuk penilaian siswa adalah 20 item (skor maksimal ideal $=100$, skor minimal ideal $=20, \bar{x}_{i}=60$ dan $S B_{i}$ $=13,3$ ), sehingga diperoleh kriteria interval kepraktisan menurut penilaian siswa seperti Tabel 6 berikut. 
Tabel 6. Kriteria Interval Kepraktisan Menurut Penilaian Siswa

\begin{tabular}{ccc}
\hline Interval & Nilai & Kategori \\
\hline $\mathrm{X}>79,95$ & $\mathrm{~A}$ & Sangat praktis \\
$73,3<\mathrm{X} \leq 79,95$ & $\mathrm{~B}$ & Praktis \\
$53,35<\mathrm{X} \leq 73,3$ & $\mathrm{C}$ & Cukup praktis \\
$40,5<\mathrm{X} \leq 53,35$ & $\mathrm{D}$ & Kurang praktis \\
$\mathrm{X} \leq 40,5$ & $\mathrm{E}$ & tidak praktis \\
\hline
\end{tabular}

Berdasarkan aspek-aspek yang digunakan dalam penilaian kepraktisan perangkat menurut siswa pada tabel 2 dan dengan memperhatikan banyaknya item setiap aspek penilaian, maka diperoleh nilai $\bar{x}_{i}$ dan $S B_{i}$ untuk masing-masing aspek penilaian yang dapat dilihat pada Tabel 7 berikut.

Tabel 7. Nilai-Nilai $\overline{x_{i}}$ dan $S B_{i}$ untuk Masing-Masing Aspek Penilaian Kepraktisan Menurut Siswa

\begin{tabular}{cccccc}
\hline Aspek Penilaian & $\begin{array}{c}\text { Banyak } \\
\text { Item }\end{array}$ & $\begin{array}{c}\text { Skor Minimum } \\
\text { Ideal }\end{array}$ & $\begin{array}{c}\text { Skor Maksimum } \\
\text { Ideal }\end{array}$ & $\overline{x_{i}}$ & $\boldsymbol{S B}_{\boldsymbol{i}}$ \\
\hline Kepraktisan LKS & 11 & 11 & 44 & 33 & 7,3 \\
Kepraktisan pmbelajaran & 9 & 9 & 45 & 27 & 6 \\
\hline
\end{tabular}

Untuk penilaian siswa, perangkat pembelajaran dikatakan praktis jika minimal $80 \%$ siswa sebagai uji coba lapangan menyatakan perangkat pembelajaran yang digunakan minimal berada pada kategori praktis.

\section{Analisis Data Keefektifan Perangkat}

Analisis terhadap keefektifan perangkat pembelajaran yang dihasilkan dilakukan terhadap: (1) analisis data keterlaksanaan pembelajaran. Analisis hasil observasi keterlaksanaan pembelajaran dilakukan dengan menghitung persentase keterlaksanaan masing-masing komponen pembelajaran pada setiap pertemuan. Adapun interval yang digunakan untuk menentukan kriteria keefektifan berdasarkan keterlaksanaan pembelajaran (Ranti, 2012, p.122) dapat dilihat pada Tabel 8 berikut.

Tabel 8. Kriteria Interval Keefektifan Berdasarkan Keterlaksanaan Pembelajaran

\begin{tabular}{ccc}
\hline Interval (\%) & Nilai & Kategori \\
\hline $86-100$ & A & Sangat baik \\
$71-85$ & B & Baik \\
$56-70$ & C & Cukup baik \\
$41-55$ & D & Kurang baik \\
$\leq 40$ & E & Baik \\
\hline
\end{tabular}

Perangkat dikatakan efektif salah satu kriterianya adalah apabila keterlaksanaan pembelajaran minimal mencapai kategori baik. Apabila belum tercapai maka dilakukan revisi berdasarkan masukan para ahli/praktisi kemudian dinilai kembali, (2) analisis data tes hasil belajar yaitu sebelum tes hasil belajar digunakan untuk menentukan keefektifan perangkat pembelajaran, maka perlu adanya analisis tentang kualitas tes. Kualitas tes digunakan pada uji coba terbatas di sekolah yang berbeda dengan sekolah pada uji coba lapangan. Kualitas tes hasil belajar pada penelitian ini diperoleh dari validitas dan uji reabilitas.

Selanjutnya, setelah analisis validitas dan tes dilakukan maka tes hasil belajar siap digunakan pada uji coba lapangan. Hal demikian dilakukan untuk mengetahui tingkat keefektifan perangkat pembelajaran matematika yang dikembangkan. Kemp menyatakan bahwa persentase penguasaan ditentukan oleh guru setelah melaksanakan pembelajaran dan batas penguasaan standar keberhasilan adalah $75 \%$.

Berdasarkan pernyataan tersebut, maka sebelum menganalisis tes hasil belajar siswa, peneliti perlu mengetahui besarnya nilai KKM pada sekolah tempat melaksanakan uji coba lapangan. Nilai KKM mata pelajaran matematika kelas X di SMAN 1 Tualang adalah 75. Adapun langkah dalam analisis data tes hasil belajar siswa yaitu hasil pekerjaan siswa dinilai berdasarkan pedoman penskoran. Nilai maksimum untuk kedua jenis tes hasil belajar siswa adalah 100 . Hasil belajar dikatakan efektif/tuntas secara individual jika mencapai nilai KKM yang telah ditetapkan, sedangkan keefektifan klasikal tercapai jika $75 \%$ sebagai subjek uji coba nilai tes hasil belajar sudah mencapai $\geq \mathrm{KKM}$.

\section{HASIL PENELITIAN DAN PEMBAHASAN}

Pengembangan perangkat dilakukan dengan menggunakan model pengembangan 4-D yang di kembangkan oleh Thiagarajan, Semmel \& Semmel (1978, p.5) yang dimodifikasi sehingga dalam penelitian ini hanya memuat proses pendefinisian, perancangan dan pengembangan. Perangkat pembelajaran yang dikembangkan adalah silabus, RPP, LKS, dan instrumen tes. 
Adapun hal-hal yang dilakukan pada tahap pendefinisian yaitu: Pertama, analisis awalakhir yaitu penulis melakukan pra-survey pada sekolah yang akan dijadikan sebagai tempat uji coba yaitu SMAN 1 Tualang dengan tujuan untuk mengetahui bagaimana kondisi pembelajaran materi trigonometri di sekolah tersebut dan masalah mendasar yang perlu diupayakan pemecahannya. Pra-survey dilakukan dengan pengamatan langsung ke kelas dan wawancara dengan guru mitra. Hasil pra-survey menunjukkan bahwa realitas pembelajaran matematika di sekolah tersebut adalah sebagai berikut: materi trigonometri termasuk salah satu materi yang sulit bagi sebagian besar siswa, guru masih kesulitan menyusun perangkat pembelajaran, belum ada sumber belajar yang memadai seperti LKS yang dikembangkan dengan model pembelajaran tertentu, pembelajaran matematika yang ada masih berupa pembelajaran konvensional yang bersifat berpusat pada guru, sehingga kurang dapat mengeksplorasi kemampuan siswa, belum tersedia perangkat pembelajaran yang mendukung siswa dalam mengembangkan kemampuannya sendiri.

Kedua, Analisis Siswa yaitu berdasarkan hasil Ulangan Harian pada materi Logika Matematika, dan nilai Mid Semester Ganjil Tahun 2013 di kelas X2 \& X3 serta informasi dari pihak sekolah, maka hasil analisis siswa yang diperoleh adalah: kemampuan matematis siswa kelas cukup beragam, dapat dikategorikan dengan kelompok tinggi, sedang, dan kurang, lingkungan belajar siswa sudah cukup kondusif atau mendukung pembelajaran karena berada di lingkungan perkotaan. Siswa yang bersekolah berasal dari berbagai Suku yaitu Melayu, Minang, Mandailing, Jawa, dan Batak. Secara umum orang tua siswa bekerja di perusahaan PT. Indah Kiat. Di Kabupaten tersebut terdapat sungai Siak yang merupakan sungai terdalam di Indonesia, beberapa jembatan yang dijadikan masyarakat sebagai tempat rekreasi, pantai, dan hutan. Hal ini kiranya dapat menjadi bahan masukan dalam menyusun sumber belajar yang kemanfaatanya dapat dilihat dan dirasakan langsung oleh siswa dalam kehidupan.

Ketiga, analisis materi yaitu materi yang dikembangkan sebagai materi penunjang pengembangan perangkat pembelajaran dengan menggunakan model pembelajaran PBL adalah materi trigonometri.

Keempat, analisis tugas yaitu yang akan dilakukan pada materi pokok trigonometri disesuaikan dengan indikator pencapaian kompetensi.

Kelima, perumusan indikator yaitu (a) mendefinisikan rumus perbandingan trigonometri, (b) menentukan nilai perbandingan trigonometri pada segitiga siku-siku, (c) menentukan nilai perbandingan trigonometri sudut khusus, (d) menentukan nilai perbandingan trigonometri dari sudut di semua kuadran, (e) menggambar grafik fungsi trigonometri, (f) menentukan persamaan fungsi trigonometri dari grafik fungsi trigonometri, (g) menyelesaikan persamaan trigonometri sederhana, (h) menjelaskan beberapa rumus identitas trigonometri dasar, (i) menyederhanakan pernyataan trigonometri, (j) membuktikan identitas trigonometri sederhana, (k) menemukan aturan sinus dan menggunakannya untuk menyelesaikan masalah yang berkaitan dengan segitiga, (1) menemukan aturan cosinus dan menggunakannya untuk menyelesaikan masalah yang berkaitan dengan segitiga, (m) menentukan kapan menggunakan aturan sinus dan cosinus, (n) menemukan rumus luas segitiga, (o) menghitung luas segitiga yang diketahui dua panjang sisi dan besar satu sudut, (p) menghitung luas segitiga yang diketahui ukuran dua sudut dan panjang satu sisi, (q) menghitung luas segitiga yang diketahui panjang ketiga sisinya, (r) mengidentifikasi masalah yang berhubungan dengan perbandingan, fungsi, persamaan dan identitas trigonometri, (s) membuat model matematika dari masalah yang berhubungan dengan perbandingan, fungsi, persamaan dan identitas trigonometri, (t) menentukan penyelesaian model matematika dari masalah yang berkaitan dengan perbandingan, fungsi, persamaan dan identitas trigonometri, (u) menafsirkan hasil penyelesaian masalah yang berkaitan dengan perbandingan, fungsi, persamaan dan identitas trigonometri.

Selanjutnya hal-hal yang dilakukan pada tahap perancangan terdiri dari empat tahap yaitu: (1) Prosedur pelaksanaan penelitian adalah perancangan prosedur kerja yang akan dilakukan. (2) Pemilihan media yaitu media belajar LKS yang telah disusun sesuai dengan tahapantahapan pada pembelajaran model PBL. Kemudian media dan alat yang bersifat umum seperti papan tulis, spidol, penggaris, busur derjat, jangka, kalkulator, dan tabel trigonometri. (3) Pemilihan format yaitu dilakukan untuk merancang isi materi, pemilihan strategi, pendekatan dan metode pembelajaran serta sumber belajar yang dikembangkan. (4) Perancangan awal perangkat adalah merancang perangkat pembelajaran yang 
terdiri dari silabus, RPP, LKS, dan instrumen tes yang disebut draft-1.

Selanjutnya pada tahap pengembangan yang dilakukan adalah: (1) penilaian kelayakan instrumen, (2) instrumen yang dikembangkan terdiri dari format validasi silabus, format validasi RPP, format validasi LKS, format validasi instrumen tes, lembar observasi keterlaksanaan pembelajaran, lembar penilaian guru, dan lembar penilaian siswa, dan (3) validasi perangkat pembelajaran yaitu perangkat yang dikembangkan dinilai oleh ahli dan praktisi dengan menggunakan format validasi yang telah dinilai kelayakannya.

\section{Hasil Uji Coba Produk}

Data diperoleh dari tiga kegiatan uji coba yang dilakukan, yaitu dari data uji coba ahli/ validasi ahli, data uji coba terbatas, dan data hasil uji coba lapangan.

Data uji coba ahli/validasi ahli dilakukan untuk menilai atau menentukan kevalidan perangkat yang dihasilkan, serta meminta masukan atau komentar dari beberapa ahli dan praktisi. Data yang diperoleh berupa data kuantitatif, yaitu skor penilaian ahli dan praktisi dan data kualitatif berupa saran atau masukan yang akan digunakan untuk memperbaiki perangkat. Validator ahli terdiri dari dua ahli pendidikan matematika dan 3 validator praktisi pelajaran matematika SMA yang mengajar kelas $\mathrm{X}$.

Kemudian data uji coba terbatas (keterbacaan) dilakukan dengan melibatkan 8 orang siswa kelas XI SMAN 1 Tualang yang dipilih berdasarkan kemampuan akademik secara heterogen, yaitu tinggi, sedang, dan kurang untuk membaca atau mengamati perangkat pembelajaran matematika yang dihasilkan. Setiap LKS diujicobakan sebanyak 2 kali, untuk melihat sejauh mana siswa dapat memahami dan menjawab permasalahan-permasalahan yang disajikan dalam LKS. Saran atau masukan-masukan tersebut dijadikan bahan untuk melakukan revisi perangkat sebelum digunakan untuk uji coba lapangan. Saran atau masukan yang diperoleh dari uji coba terbatas adalah sebagai berikut: (1) bahasa yang digunakan dalam LKS masih ada yang kurang jelas, (2) tampilan gambar yang ada pada LKS sudah cukup menarik bagi siswa, (3) setiap LKS dimulai dengan masalah kehidupan nyata sehari-hari beserta gambar yang menarik yang berkaitan dengan indikator pembelajaran, sehingga kemanfaatan mempelajari materi tersebut langsung dapat diketahui oleh siswa, (4) soal-soal tes hasil belajar sudah cukup dipahami oleh siswa baik soal pilihan ganda maupun soal uraian, (5) ketersediaan waktu untuk menyelesaikan LKS sudah cukup, namun ada beberapa LKS waktu yang disediakan tidak cukup seperti LKS 2, (6) LKS memberikan kesempatan dan ruang bagi siswa untuk berperan aktif dari awal sampai akhir pembelajaran, (7) LKS memberikan kesempatan yang cukup bagi siswa untuk memanfaatkan atau menggabungkan pengetahuan yang telah dimiliki sebelumnya untuk memperoleh pengetahuan baru, (8) tempat untuk menuliskan jawaban siswa yang tersedia pada LKS perlu diperbesar, (9) hal-hal yang perlu disimpulkan dalam setiap pembelajaran dengan bantuan LKS sangat menunjang ketercapaian kompetensi, namun masih ada yang diminta kurang spesifik. Seperti dalam kesimpulan untuk LKS 5.

Selanjutnya uji coba lapangan dilakukan pada siswa kelas X2 dan X3 SMAN 1 Tualang. Dari uji coba lapangan diperoleh tentang: (1) silabus, guru yang menggunakan silabus sebagai panduan dalam pelaksanaan pembelajaran di kelas menyimpulkan bahwa tidak ada kekeliruan atau hal-hal yang tidak dipahami dalam penggunaan silabus, namun pada pertemuan pertama ada langkah-langkah pada kegiatan pembelajaran yang tidak terlaksana sesuai dengan yang dituangkan dalam silabus, diantaranya yaitu guru tidak membimbing dan meminta siswa untuk mengidentifikasi masalah-masalah kehidupan sehari-hari yang berkaitan dengan trigonometri yang diharapkan dapat meningkatkan minat siswa untuk mengikuti pembelajaran, guru langsung mengarahkan siswa untuk berdiskusi. (2) RPP, guru yang menggunakan RPP sebagai panduan dalam pelaksanaan pembelajaran di kelas menyimpulkan bahwa kurangnya waktu yang tersedia dalam RPP. Untuk pembelajaran dengan PBL dibutuhkan waktu yang relatif lebih lama, karena siswa bersama teman-teman kelompok dituntut membangun sendiri pengetahuannya dengan bantuan LKS yang disusun oleh penulis. (3) LKS, guru yang menggunakan LKS sebagai panduan dalam pelaksanaan pembelajaran di kelas menyimpulkan secara umum LKS menarik dan masalah-masalah yang disajikan ada yang bisa dengan mudah diselesaikan, sehingga para siswa antusias selama pembelajaran. (4) instrumen tes atau tes hasil belajar yaitu soal tes pilihan ganda dan soal uraian yang sudah divalidasi oleh ahli/praktisi, diujicobakan pada kelas XI dengan jumlah 32 orang, yang akan digunakan untuk mengukur hasil belajar 
siswa setelah melakukan pembelajaran sebanyak $8 \mathrm{x}$ pertemuan.

\section{Keterlaksanaan Pembelajaran di Kelas}

Orientasi siswa pada masalah yaitu para siswa antusias mendengarkan dan memperhatikan ketika guru mengkomunikasikan tujuan pembelajaran dan rencana kegiatan pembelajaran yang akan dilaksanakan dengan menggunakan model PBL. Guru juga memberikan motivasi, serta memberikan apersepsi yang akan membantu siswa mengerjakan LM dan LKS.

Penyelidikan individu dan kelompok yaitu siswa membaca, memahami, dan mencoba menyelesaikan masalah dalam LKS. Guru memberikan scaffolding untuk membantu mengembangkan pikiran siswa yang bekerja dalam kelompok,

Mengembangkan dan menyajikan hasil karya yaitu siswa mencoba menjawab LM dan mempersentasikannya di depan kelas. Untuk LM-6 belum ada siswa ataupun kelompok yang bisa menjawab dengan benar, sehingga guru mengarahkan agar siswa langsung mengerjakan LKS yang telah disediakan penulis. Pada tahap mengembangkan, untuk LKS-6 ada kelompok yang menurunkan aturan cosinus dengan dua cara. Ketika dianalisis bersama oleh siswa dan guru, kedua cara siswa tersebut benar dengan cara yang berbeda, akibatnya mereka semakin antusias untuk belajar, karena bisa menurunkan rumus aturan cosinus dengan benar dengan lebih dari satu cara. Setelah siswa selesai mengerjakan LKS dan mempersentasikan hasil kerja mereka, maka siswa diminta kembali mengerjakan LM-6 yang tertunda dan ternyata para siswa bisa mengerjakan dengan benar.

Menganalisis proses penyelesaian masalah yaitu guru membimbing siswa untuk menyelidiki kebenaran masing-masing jawaban yang ditampilkan di papan tulis. Dari dua jenis jawaban berbeda yang dituliskan siswa di papan tulis yaitu hasil kerja dari kelompok I \& II, setelah dianalisi guru beserta siswa, hasil kerja kelompok II terjadi kekaliruan yaitu menjumlahkan langsung bentuk pecahan yang penyebutnya berbeda, yang seharusnya disamakan dahulu baru bisa dijumlahkan. Dari analisis tersebut siswa mengetahui kekeliruan atas langkah-langkah jawaban mereka,

Mengevaluasi pemecahan masalah yaitu sebelum melakukan penilaian yang dilaksanakan pada setiap pertemuan, siswa dengan bimbingan guru merangkum pembelajaran yang telah dilaksanakan. Selanjutnya guru memberikan soal evaluasi yang dikerjakan oleh masing-masing siswa untuk melihat apakah siswa sudah benarbenar memahami tentang materi yang telah dipelajari.

\section{Analisis Data}

Berdasarkan data yang diperoleh dari validasi ahli, maka dilakukan analisis untuk menentukan kevalidan silabus yaitu data kuantitatif yang berupa skor penilaian ahli dan praktisi terhadap kevalidan silabus dikonversi menjadi data kualitatif untuk menentukan kategori kevalidan silabus yang dihasilkan. Silabus dikatakan layak digunakan jika skor total penilaian minimal berada pada kategori valid, yaitu > 132 . Untuk kevalidan RPP yaitu data kuantitatif berupa skor penilaian ahli dan praktisi terhadap kevalidan RPP kemudian dikonversi menjadi data kualitatif untuk menentukan kategori kevalidan RPP. RPP dikatakan valid dan layak digunakan jika skor total penilaian minimal berada pada kategori valid, yaitu > 198. Berdasarkan hasil analisis data, maka diperoleh skor total validasi RPP yaitu 221, maka RPP yang dihasilkan dikategorikan sangat valid. Untuk kevalidan LKS yaitu data kuantitatif berupa skor penilaian ahli dan praktisi terhadap LKS kemudian dikonversi menjadi data kualitatif untuk menentukan kategori kevalidan LKS. LKS dikatakan valid dan layak digunakan jika skor total penilaian minimal berada pada kategori valid, yaitu > 84,3 . Berdasarkan hasil analisis data, maka diperoleh skor total validasi LKS adalah 93, maka LKS yang dihasilkan dikategorikan sangat valid.

Selanjutnya analisis data kepraktisan perangkat dilihat dari: (1) penilaian guru yaitu dilakukan dengan mengkonversi skor kuantitatif yang diperoleh menjadi data kualitatif menggunakan interval kriteria kepraktisan. Berdasarkan hasil analisis yang dilakukan, maka dapat dilihat kategori tingkat kepraktisan perangkat dari penilaian guru yaitu rata-rata keseluruhan pembelajaran untuk kelas X2 adalah 166,9 dan X3 166,1 sehingga disimpulkan perangkat termasuk kategori sangat praktis. Demikian halnya untuk kedua kelas yaitu 166,5 dengan kategori sangat praktis. (2) Penilaian siswa yaitu dilakukan dengan mengkonversi skor kuantitatif yang diperoleh menjadi data kualitatif menggunakan interval kriteria kepraktisan. Penilaian ini dilakukan oleh semua siswa kelas X2 \& X3 yang masing-masing kelas dengan jumlah siswa 32 menggunakan produk yang dikembangkan yaitu LKS. Skor total penilaian untuk keseluruhan 
pembelajaran pada kelas X2 yaitu $79,1 \%$ dan X3 yaitu 78,9 maka perangkat termasuk kategori praktis. Demikian halnya dari kedua kelas ratarata untuk keseluruhan pembelajaran adalah 79 sehingga perangkat termasuk kategori praktis.

Kemudian analisis data keefektifan perangkat pembelajaran dapat diukur berdasarkan: (1) keterlaksanaan pembelajaran di kelas yaitu hasil observasi keterlaksanaan pembelajaran pada masing-masing kelas yaitu kelas X2 \& X3 berada pada kategori sangat baik. Demikian halnya dari gabungan kedua kelas memperoleh kategori sangat baik. (2) Data tes hasil belajar (THB) yaitu hasil belajar siswa yang berupa nilai dari soal pilihan ganda dan uraian. Nilai maksimum untuk soal pilihan ganda dan uraian masing-masing 50. Nilai maksimum untuk kedua tes adalah 100. Nilai untuk pilihan ganda diperoleh dengan mengalikan banyak jawaban yang benar dengan 3,33. Kemudian untuk uraian sesuai dengan rubrik pensekoran yang telah dibuat oleh penulis. Secara grafik ditunjukkan tingkat ketuntasan belajar siswa kelas X2 yang telah mengikuti pembelajaran dengan PBL.

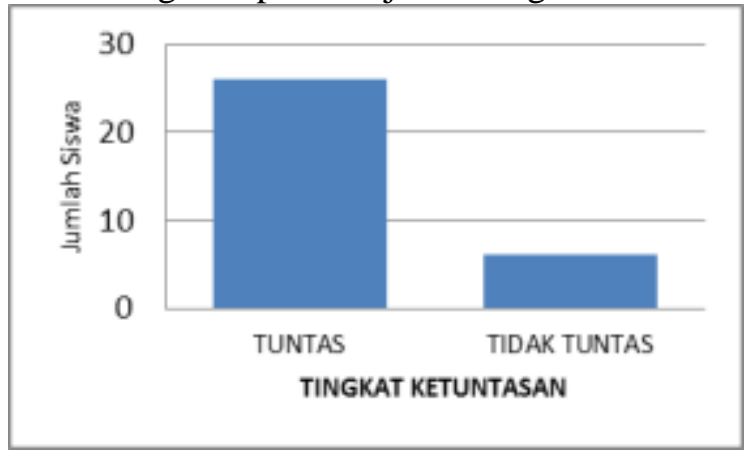

Gambar 3. Tingkat Ketuntasan Belajar Siswa Kelas X2

Berdasarkan hasil analisis data yang dilakukan, maka diperoleh persentase Berdasarkan hasil analisis data yang dilakukan, maka diperoleh bahwa persentase siswa yang mencapai nilai KKM yaitu sebanyak 26 orang dengan ketuntasan klasikal 81,3\%. Hasil tes belajar juga telah mencapai ketuntasan secara individual.

Selanjutnya Secara grafik ditunjukkan tingkat ketuntasan belajar kelas X3 setelah melaksanakan pembelajaran.

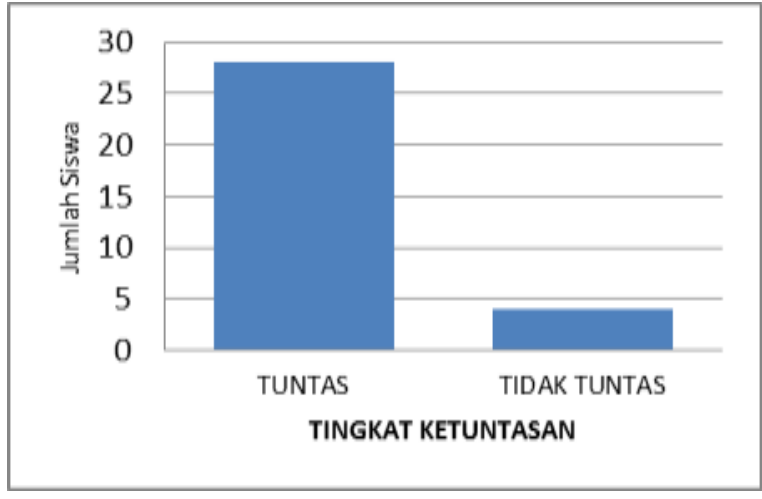

Gambar 4. Tingkat Ketuntasan Belajar Siswa Kelas X3

Berdasarkan hasil analisis data yang dilakukan, maka diperoleh bahwa persentase siswa yang mencapai nilai KKM lebih dari $80 \%$, yaitu sebanyak 28 siswa dengan nilai ketuntasan secara klasikal 87,5\%. Hasil tes belajar juga telah mencapai ketuntasan secara individual.

Dari hasil analisis data di atas, dapat disimpulkan bahwa pengembangan perangkat dengan menggunakan model pembelajaran PBL pada materi trigonometri telah memenuhi kriteria efektif.

\section{Revisi Produk}

Hasil uji coba berupa masukan dari para ahli dan praktisi yang dijadikan bahan untuk melakukan perbaikan terhadap produk perangkat pembelajaran yang dihasilkan, yang terdiri dari silabus RPP, LKS, dan instrumen tes. Revisi dilakukan berdasarkan tiga kegiatan uji coba, yaitu: (1) revisi produk hasil uji coba ahli/ validasi ahli yang berupa silabus, RPP, LKS, dan THB. (2) revisi hasil uji coba terbatas. (3) Revisi hasil uji coba lapangan.

Revisi produk hasil uji coba ahli/validasi ahli terhadap silabus dilakukan berdasarkan masukan dari para ahli dan praktisi terhadap silabus yaitu: masih ada indikator pencapaian yang tidak operasional, beberapa contoh instrumen perlu diperbaiki, bahasa dan tata tulis perlu diperbaiki, kegiatan pembelajaran perlu diperjelas lagi. Revisi produk hasil uji coba ahli/validasi ahli yang berupa RPP dilakukan berdasarkan masukan dari para ahli dan praktisi terhadap silabus yaitu: (1) Bahasa dan tata tulis perlu diperbaiki, (2) penulisan kalimat-kalimat (matematika) masih perlu diperbaiki dan tidak konsisten, (3) diperjelas atau diekplisitkan pada kegiatan apersepsi dari masing-masing RPP. Seperti pada RPP 6, (4) diperjelas atau diekplisitkan motivasi yang akan diberikan kepada siswa sehingga mereka tertarik untuk belajar, (5) 
membuat soal latihan/PR setiap selesai pembelajaran. Revisi produk hasil uji coba ahli/validasi ahli yang berupa LKS dilakukan berdasarkan masukan dari para ahli dan praktisi yaitu: (1) Penulisan kalimat (matematika) dan gambargambar pada LKS perlu dilengkapi atau diperbaiki lagi, (2) masih ada Lembar Masalah (LM) yang disajikan kurang jelas (LKS 6), (3) masih ada Lembar Masalah (LM) yang disajikan tidak relevan, (5) redaksi gambar tidak jelas (LKS 1), (6) beberapa sajian LKS perlu ditambah arahan (LKS 1 dan LKS 6), (7) beberapa kalimat dalam Lembar Masalah perlu diperbaiki (LM-2, LM-3, LM-4, dan LM-5), (8) langkah-langkah menemukan rumus kurang jelas (LKS-7), (9) tidak sama besar sudut yang diketahui dalam lembar masalah dengan gambar yang disajikan dan lembar masalah. Kemudian Revisi produk hasil uji coba ahli/validasi ahli yang berupa THB dilakukan berdasarkan masukan dari para ahli dan praktisi yaitu gambar grafik pada soal kurang jelas, soal yang dibuat tidak sesuai indikator, dan soal belum dilengkapi gambar.

Revisi hasil uji coba terbatas yaitu: (1) revisi keterbacaan LKS oleh siswa yaitu petunjuk-petunjuk kerja LKS ditambah, dan tempat yang disediakan untuk jawaban siswa ditambahkan. (2) Revisi keterbacaan oleh guru yang berupa silabus yaitu memperjelas, yang dilakukan dalam kegiatan pembelajaran, penilaian ditambahkan dengan soal-soal latihan atau PR, dan kegiatan yang diberikan belum menunjukkan langkah model PBL. Revisi keterbacaan oleh guru yang berupa RPP yaitu melampirkan soal penilaian di setiap RPP, menuliskan alat yang dibutuhkan dalam pelaksanaan pembelajaran yaitu tabel trigonometri dan kalkulator. Revisi keterbacaan oleh guru yang berupa LKS yaitu bahasa yang digunakan dalam LKS masih ada yang kurang jelas, dan materi yang disajikan dalam LKS masih kurang jelas. Setelah dilakukan revisi, maka diperoleh perangkat pembelajaran matematika dengan model PBL yang meliputi silabus, RPP, LKS, dan instrumen tes yang layak dan siap digunakan untuk uji coba lapangan yang akan dilakukan pada siswa SMAN 1 Tualang sebagai subjek uji coba lapangan.

Revisi hasil uji coba lapangan terhadap silabus yaitu agar lebih memperhatikan tata tulis pada silabus. Revisi hasil uji coba lapangan terhadap RPP yaitu: agar lebih memperhatikan tata tulis, mengaitkan setiap pembelajaran dengan kehidupan sehari-hari siswa, mengaitkan pembelajaran yang akan dilakukan dengan pengetahuan dan keterampilan yang dimiliki siswa sebelumnya (apersepsi), waktu yang diberikan untuk RPP 2 kurang. Revisi hasil uji coba lapangan terhadap LKS yaitu memperbesar tempat untuk menulis jawaban siswa, dan tata tulis masih ada yang salah serta masih dibutuhkan arahan untuk mulai mengerjakan LKS.

\section{Kajian Produk Akhir}

Produk perangkat yang dihasilkan telah memenuhi kriteria sangat valid berdasarkan hasil uji coba terbatas dan validasi ahli/praktisi. Kelayakan tersebut dilihat dari skor validitas silabus yaitu 153 dengan kategori sangat valid. Skor validitas RPP yaitu 221 dengan kategori sangat valid. Skor validitas LKS yaitu 93 dengan kategori sangat valid. Hasil validitas tes hasil belajar dengan kategori valid atau layak digunakan dengan revisi (LDR).

Berdasarkan hasil uji coba lapangan diperoleh bahwa perangkat yang dihasilkan telah memenuhi kriteria praktis. Data hasil lembar penilaian guru terhadap perangkat yang dikembangkan mencapai skor 166,5 dengan kategori sangat praktis dan data hasil penilaian siswa mencapai skor 79 dengan kategori praktis.

Keefektifan perangkat ditinjau dari hasil observasi keterlaksanaan pembelajaran di kelas dan dari ketercapaian ketuntasan belajar siswa secara individual dan klasikal dari dua kelas yang menjadi tempat uji coba. Hasil observasi keterlaksanaan pembelajaran mencapai skor $88 \%$ dengan kategori sangat baik, dan ditinjau dari hasil belajar bahwa pada setiap kelas, presentase siswa yang tuntas mencapai KKM, yaitu lebih dari $75 \%$, yaitu kelas X2 sebanyak $78,1 \%$, dan X3 sebesar 87,5\%. Begitu juga secara keseluruhan presentase siswa dari kedua kelas yang tuntas adalah sebanyak $82,8 \%$. Jadi, pengembangan perangkat dengan menggunakan model PBL pada materi trigonometri yang dihasilkan telah memenuhi kriteria efektif.

Berdasarkan tercapainya kriteria valid, praktis dan efektif dari perangkat pembelajaran, maka diperoleh suatu produk akhir berupa perangkat pembelajaran yang valid dan layak digunakan pada pembelajaran.

\section{SIMPULAN DAN SARAN}

\section{Simpulan tentang Produk}

Produk yang dihasilkan dari pengembangan perangkat dengan menggunakan model pembelajaran problem based learning yang meliputi silabus, rencana pelaksanaan pembel- 
ajaran (RPP), lembar kegiatan siswa (LKS), dan instrumen tes layak digunakan. Model pengembangan yang digunakan adalah model pengembangan Thiagrajan, Semmel, dan Semmel yang terdiri dari tiga tahap yaitu pendefinisian, perancangan, dan pengembangan.

Perangkat pembelajaran yang dihasilkan, yang terdiri dari silabus, RPP, LKS, dan instrumen tes sudah mencapai kategori sangat valid berdasarkan penilaian dari validator ahli dan praktisi pendidikan matematika. Setelah melalui tahap uji coba lapangan, hasilnya menunjukkan kategori praktis dan efektif. Untuk kepraktisan perangkat mencapai kategori praktis dilihat dari penilaian siswa, dan dilihat dari penilaian guru menunjukkan kategori sangat praktis. Keefektifan dilihat dari ketuntasan hasil belajar siswa dan observasi keterlaksanaan pembelajaran di kelas. Secara klasikal ketuntasan belajar siswa 82,8\%. Hasil observasi keterlaksanaan pembelajaran mencapai skor $88 \%$ dengan kategori sangat baik. Secara keseluruhan hasil penelitian menunjukkan bahwa perangkat pembelajaran yang dikembangkan layak digunakan.

\section{Saran Pemanfaatan Produk}

Saran pemanfaatan produk yang dikembangkan adalah sebagai berikut: (1) perangkat pembelajaran yang telah dihasilkan yang terdiri dari silabus, RPP, LKS, dan instrumen tes pada materi trigonometri telah memenuhi kriteria valid, praktis, dan efektif, sehingga layak digunakan pada pembelajaran di kelas, (2) Produk yang dikembangkan dapat dijadikan sebagai contoh perangkat pembelajaran matematika khususnya untuk materi trigonometri.

\section{DAFTAR PUSTAKA}

Amir, M.T. (2009). Inovasi pendidikan melalui problem based learning. Bagaimana pendidik memberdayakan pembelajar di era pengetahuan. Jakarta: Kencana Prenada Media Group.

Azwar, Saifuddin. (2010). Tes prestasi (Fungsi pengembangan pengukuran prestasi belajar). Yogyakarta: Pustaka Pelajar.

Arends, I.R., \& Kilcher, A. (2010). Teaching for student learning. New York and London: Taylor \& Francis Group. McGraw Companies, Inc.
Arends, I.R. (2007). Learning to teach. (7rd ed.). New York: McGraw Companies, Inc.

BSNP.(2006). Panduan penyusunan kurikulum tingkat satuan pendidikan jenjang pendidikan dasar dan menengah. Jakarta: BSNP Depdiknas.

Cheong, F. (2008). Using a problem-based learning approach to teach an intelligent systems course. Journal of Information Technology Education Volume 7.

Delisle, R. (1997). How to use problem-based learning in the classroom. New York: Association for Supervision and Curriculum Development.

Depdiknas. (2006). Peraturan Menteri Pendidikan Nasional Nomor 22 Tahun 2006, tentang Standar Isi.

Depdiknas. (2007). Peraturan Menteri Pendidikan Nasional Nomor 41 Tahun 2007, tentang Standar Proses.

Kemp, J. E. (1985). The instructional design process. New York: Harper \& Row.

Levin, B.B. (2001). Energizing teacher education and professional development with problem-based learning. New York: Association for Supervision and Curriculum Development (ASCD).

Nieveen, N. (1999). Prototying to reach product quality dalam Plomp, T; Nieveen, N., Gustafson, K., Branch, R. M., \& Van den Akker, $J(e d s)$. Design approaches and tools in education and training. London: Kluwer Academic Publisher.

Ranti, M.G. (2012). Pengembangan perangkat pembelajaran Matematika bilingual SMA kelas X. Tesis Magister, tidak Diterbitkan, Universitas Negeri Yogyakarta, Yogyakarta.

Schunk, D.H. (2008). Learning theorie. An education perspective. United States of America: Pearson Prentice Hall.

Thiagarajan, S., Semmel, D., \& Semmel, M.I. (1974). Instructional development for training teachers of exceptional children. A Sourse Book. Blomington: Central for Innovation on TeachingThe Handicapped 